\title{
THE EU AT SIXTY: \\ A WATERSHED OR BUSINESS AS USUAL? (COMPARING GREXIT TO BREXIT)
}

\author{
László CSABA
}

This essay is an attempt to put two major events in a broader perspective. Comparing the two dominant discourses, we attempt to address the meaning and thus the strategic options of European integration at a time of crisis. A political economy approach is adopted to explain the different dynamics of the two cases and to specify conditions for a more efficient integration in the years to come. Some proposals for policy reform conclude.

Keywords: European Union, UK, Greece, community method, crisis management, inter-governmentalism, ESM, financial market integration, political economy, cohesion, CFSP, special relationships

JEL classification indices: F5, E6, O5

\section{INTRODUCTION}

The process of European integration has been stumbling at least since the FrenchDutch (2005) and Irish (2008) referenda rejecting the formalisation of the principle of the "ever closer union" in the form of the European Constitutional Treaty elaborated after many years of laborious efforts. These events were already clear signals of the growing drift between increasingly globalised and Europeanised

László Csaba, Member of the Hungarian Academy of Sciences and Academia Europaea, Distinguished Professor of international political economy at CEU and Corvinus University of Budapest. More on this personal website: www.csabal.com E-mail: csabal@ceu.edu 
elites on the one hand, and the electorate, or the broader public, on the other. Nobody really doubted that most voters, especially among the naysayers, never bothered to read even the major points of the complex legal document, let alone its fine print. While the message was basically meant to teach a lesson to politicians on basically domestic issues such as unemployment, migration, and other social concerns, the outcome has proven truly fatal for the federalist-centralising tendencies inherent in what is usually termed as the "Community method" (Csaba 2009a).

As a consequence, and also following intricate and opaque deals and arrangements stuck among major actors of the EU, that is the Parliament, the Commission, and the Council, ${ }^{1}$ the EU has become more inter-governmental and less supra-national than it appears to outsiders (Bickerton et al. 2015). While the Commission, especially since Jean-Claude Juncker's ascent to Presidency, has become more political, and so has the Parliament, fundamental decisions continued to be made in national capitals. Side-deals reached around the activity of the Franco-German tandem and the changing geometry of its supporters, as documented in the volume cited above. As a matter of fact, the Lisbon Treaty replacing the EU Constitution - also dubbed the Reform Treaty - effective from January $2009,{ }^{2}$ has rendered this feature even more explicit.

Let us note: the series of crisis-management measures, which have become the modus operandi of the Union ever since the spillover of the global financial crisis in 2008, has pushed supranational, centralised solutions to the foreground. Whenever the troika was involved, or the new crisis management measures were introduced, centralisation increased. This included the cross-border banking resolution, the European Stability Mechanism, and the entire set of measures, which are currently merged under the heading of fiscal and banking union (Laanoo 2015; Kudrna 2016). In sum: innovations have all increased centralised, technocratic supervision over issues that used to be decided on exclusively national grounds, and not only in the economic sphere.

The growing drift between legal/formal decentralisation and substantive/economic centralisation is also reflected by the fact that most of the novelties could not be incorporated into the Treaty on the European Union. These all required separate inter-governmental agreements that exist outside the scope of the Treaty, its letter and spirit alike. As this has been the case not only for a transient period

1 When it came to crisis management, the ECB and even an external player, the IMF, has been involved in the form of a major legal and political innovation, called the troika.

2 Consolidated version of the Treaty on the Functioning of the EU, available at www.europa. eu/legal-content/EN/TXT/?uri=celex\%3A121012E\%2FTXT (accessed September 22, 2016). 
of 4-5 months, until appropriate legal arrangements could be devised, but continues to be the case for 4-5 years, one must see this as an objectionable state of affairs. This holds even if one were to subscribe unconditionally to the economics behind the new solutions of the Fiscal and Banking Union. This is more than problematic on its own right, especially in a Community based on jointly adopted values and norms, such as the rule of law, or a Community of values, as the Europeanisation literature would have it.

Thus, our first observation is that the drift between "poetry and reality" (Dichtung und Wahrheit) on the fundamental features of European integration has been showing clear trends years before populist movements started to populate legislations in the national and European arenas alike. In both cases, we are confronted with manifestations of a complex and multi-faceted reality, where the political and the economic, the legal and the administrative, and the legitimate and the rational do not necessarily overlap. Moreover, most theories of integration are of little avail, as long as they generalise past experience and tend to be unprepared for the challenges posed by external shocks, internal reactions, and the often unintended side-effects of the interaction among those that tend to dominate outcomes (Csaba 2009b). In both cases discussed here, the outcomes are by and large the opposite of what the majority of expert views would have had before the actual events materialised. This is paradoxical and requires interpretation.

\section{THE DOG THAT DIDN'T BARK: GREECE STAYS IN THE EMU}

One of the most often formulated suggestions in both the academic literature and in the daily press has been the idea that Greece should leave the EMU. The most vocal, and perhaps most influential, author voicing this view has been Nobel laureate Paul Krugman (2015), who called for the devaluation of the exchange rate cum unlimited and unconditional external funding.

This has not happened, despite the fact that in the 2015 referendum, the Greek electorate supported its radical government in rejecting the tough terms of the proposed bailout package. Why so, if the alternative is so easy and rational?

First, let us note: for the time being, there is no legal way of exiting the EMU without leaving the European Union. The difference between currency pegging, as practised in many countries in the 1980s and 1990s (mostly to the D-Mark in Europe and to the US dollar in Latin America and East Asia), and the pledge to switch from the national currency to the euro is precisely the irrevocability of the pledge. According to all opinion polls available to date, 75 to $85 \%$ of Greeks still want to stay in both the EU and the EMU, a factor that binds the hands of any government. 
Second, let us presume that the drachma returns, following Krugman's reference to the floating Argentinian peso. This would immediately trigger a crisis of confidence, leading to the drastic nominal and real devaluation of all assets, financial and real alike. In turn, just because of simple arithmetics, outstandings would sky-rocket. The public debt to GDP ratio, currently accounting for $182.7 \%$ of GDP, ${ }^{3}$ at a devaluation of $30 \%$, would increase to about $240 \%$, i.e. Japanese standards, without, however, being covered by Japanese levels of domestic savings. Let us note, that while private assets would also be devalued, while outstandings explode, funding any activity could become a hassle. And it is easy to see how a vicious circle could emerge. Argentina, Krugman's example, has yet to present itself as a credible case of economic success.

In order to pre-empt the worst-case scenario, not only has Greek debt been repeatedly re-scheduled by the troika, leading to a minimum of EUR $250 \mathrm{bn}$ in terms of transfers, but the European Central Bank (ECB) has also provided liquidity, unlimited amounts of liquidity. First through TARGET2, the system pumping cash even into the obviously bankrupt Greek commercial banks, then by the outright monetary transactions, and more recently by the asset purchase programmes, which may currently include direct purchases of government and corporate bonds. ${ }^{4}$

Without being too technical, we may agree with Visvizi (2014) that during the chaos of 2011, Grexit was perhaps an open option for policy-makers, but it later definitely ceased to be the case. Positive growth, forecast by the Commission report cited above for 2017 (2.7\%), the first in many years, will be the answer, as has been the case elsewhere, for example in the Baltics.

Why has Grexit ceased to be an option? The three arguments listed above would already suffice. However, it is perhaps even more important to be familiar with two additional insights. First, if output decline is not caused by excessive fiscal austerity, but by structural factors, or - as in Greece - institutional disintegration leading to state incapacity to deliver on any policy field, this may actually superimpose its logic on adjustment plans. Decline becomes self-perpetuating. Second, by the same token, if soft budget constraints apply on the macro-level, the state becomes crucially dependent on external funding (Györffy 2016). Thus, cutting the umbilical cord - primarily to the more covert, but larger inflow of ECB funds - could have been suicidal for Greece, for the public and private sector alike, in the prime meaning of the word.

3 www.ec..europa.eu/economy_finance.eu/countries/greece_en.htm (last accessed September 14, 2016).

4 www.ecb.europa.eu/mopo/implement/html/index_en/htm:l European Central Bank: The Eurosystem's instruments (accessed September 14, 2016). 
If we consider the decisive role played by reputational and communication factors on global capital markets, where governmental guarantees - as a form of verbal intervention - may be stronger than actual delivery on improving fundamentals (as the trade balance), the seemingly paradoxical behaviour of successive Greek governments becomes trivial.

Let us note: this is not about the asymmetric "core-periphery relations in the EU", the alleged pressure from the North, especially from the Germans, to sell their agenda. Nor is it a unilateral mercantilist approach on an unwilling South, as often portrayed in the literature. ${ }^{5}$ It is either a simple profit-maximising/utilitarian strategy, or a largely emotionally-based, but materially rewarding attachment to Europe, or a combination of both.

\section{THE DOG THAT BARKED - AND ALSO BIT: BREXIT}

It should not have come as a surprise, but it did: the UK electorate voted, with a convincing majority and high turnout rate, to leave the EU. Experts tended to consider it improbable and improper - voters decided otherwise. In a way, it has been more of the same: a continuation of the story ever since the derailment of the European Constitutional Treaty.

There are two basic narratives on the outcome. One claims British uniqueness, the other blames the decline of the political class. The two are perhaps more complementary rather than contradictory readings of events.

Historians tend to argue, with reference to long-run path dependence, that Britain has never been an integral part of (continental) Europe. Therefore, its participation in the European project has always been somewhat artificial. Its status was closer to an observer, an external member, or an associate member, rather than of a major, formative power of the Community. As the wording of the title by a professor of government at King's College (Simms 2016a) already indicates: the English Channel is seen largely as a physical expression of a basically unbridgeable cultural, political, and institutional difference from whatever has been the case "over there", on the Continent.

Indeed, the United Kingdom never became a fully-fledged member of the Community. Not only because of its stormy path to membership and subsequent conflict-ridden relationship with the rest. The latter is exemplified by the infamous British rebate from EU funds, its attempted but failed membership in the EMU in 1992, and, more recently, the major disagreements over the military interventions in Iraq (2003) and Libya (2011). Meanwhile, the UK has never renounced the 
"special relationship" to the United States for the sake of the Common Foreign and Security Policy within the EU, although - as a nuclear power - it has played a prominent role in shaping the latter. Britain has been a forefighter for European joint military forces, not supported by the small and neutral members. In contrast, it never joined the Schengen zone. Britain conspicuously stayed out of all major innovations, particularly the Fiscal and Banking Union, retaining national control over the City and its global financial sector. Not only has there been a lack of emotional identification with the EU project, comparable say to the Netherlands, but resentment over the rulings of the European Court of Justice and basically of any supra-national measure - imagined or real - indicated British separateness.

Supporters of this line see a kind of historic inevitability in the outcome of the vote, insofar as they portray British constitutional, legal, and institutional arrangements to be fundamentally not liable to any meaningful Europeanisation in legal, political, or implementation terms. In short: the UK has never been in Europe, thus it is only proper if the political and legal expression of this stand-alone attitude is expressed through Brexit.

But there is a competing view. Ever since Harold Wilson's famous admission of the UK no longer being a great power, but a middle-sized power, the need to act collectively, rather than individually, no longer counted as high treason. Replicating arguments well known from French and German politics, the European platform tended to be seen as a natural outlet for channelling and achieving British interest without being seen as colonial, imperial, or simply traditional great power politics. In the 1980s, the 1990s, and the first decade of this millennium, this counted as a platitude, not really in need of justification or documentation.

Adherents of this line tend to see the outcome as a failure of the British political class in general, and of the leadership, or the lack of profiled leadership, by David Cameron and his Conservatives in particular. In this reading, the gradual mainstreaming of formerly exotic ideas of the UKIP such as playing the antiimmigration card, the feeling of marginalisation through the euro zone (and being left out of major decisions in the Euro group), the strange coalition of the City, the tabloids, and the Eurosceptic wing of the Conservatives have gradually made an idea acceptable, which looked lunatic even a decade ago (McShane 2016).

Expanding on this line, other commentators see the outcome as a revolt against established lines of politics, especially of the way politics is conducted by the closed shop of an elite (Mosbacher - Wiesman 2016). In the latter reading, the UK is by no means exceptional: its evolution fits in the overall European, and American, trend of growing populism. In short, reflecting the drift between elites and masses, quality press and high-brow academic journals $v s$. infotainment in electronic media and the rule of social media, and lack of quality control on internet sources have together created a new explosive. This challenges established 
moderate politics by both Left and Right, sees coalitions as betrayal of principles, and highlights alienation from institutions. Therefore, amalgamations of diverse tendencies may unite in an ad-hoc manner in coincidental coalitions. This is how Five Stars in Italy or AfD in Germany works.

It is hardly surprising or unique to see personal ambitions and overall dissatisfaction in this line of reasoning, combined with lies and misrepresentations, becoming effective in the media. It was telling to see Boris Johnson collapsing or Nigael Farrage resigning upon their own victory. Actually, several months after the change of government, the newly appointed minister for managing exit talks openly admitted: they have yet to elaborate guidelines, let alone measures, for how the UK is to leave the Community. ${ }^{6}$ This seems ironic in what was known as "the mother of all democracies". Precisely: it is quite a long way from the idea of a representative government, provided voters' preferences are to be aggregated, if any representation is to be taken only half-seriously. In other words: there was no plan or project on how to attain those goals, which won a convincing majority with a turnout of $72 \%$. But - a majority for precisely what?

Similarly to the Greek case, expert opinion tended to over-estimate rational and material factors in line with standard micro-economic theory. By contrast, disregarding emotional and communicational factors as well as changes in the composition of both society and media, especially the impact of social media, it has missed the point. Normative and descriptive elements were mixed up. This is a problem for analysts, even if we have yet to figure out the precise mechanisms how the reversal of UK membership in the EU has been orchestrated.

Let us now make some fundamental observations, which have a profound relevance for long-term perspectives. First, the British economy has never been integrated into that of continental Europe, anything comparable to East and Central European economies, Austria, or Belgium. Most British trade has traditionally been transacted with "the rest of the world", not with continental Europe. Trade cycles have never been synchronised, British firms tended to go global rather than focusing on the single market. Second, financial integration to the global rather than the continental economy has never ceased to exist during EU membership. Asymmetric integration of financial markets has therefore remained a formative feature of the UK. The City and the UK financial sector have long played an independent global role, not constrained by European regulations and concerns. The depth and sophistication of the London capital market equals only that in New York, thus a joint regulation - in the form of a Banking Union does not seem to serve its interest. Third, British foreign and security policy has

UK Brexit minister promises public guidelines for EU exit talks (Euractiv, September 15, 2016). 
long tended to remain dissimilar to any common European line. Despite being a medium-sized power in terms of Realpolitik, and not least because of its nuclear status and effective combat forces, the UK has remained a special partner for both the USA and the rest of the EU. This status has now been shaken and questioned, raising new doubts about how British interests might be articulated, and how the common Atlantic line on security matters can be sustained (Olivier - Williams 2016). These issues are of immediate relevance for basically each issue of strategic importance, be that solving the Syrian conflict, coming to terms with massive irregular migration from non-western civilisations, entrusting international agencies with supervising financial flows, or concluding the Transatlantic Trade and Investment Partnership agreement at long last.

\section{THE UNION AFTER BREXIT: RENEWAL FOR WHAT?}

At the time of writing, think tanks in Brussels and in national capitals have already begun to work full speed to find new arrangements for a post-Brexit Europe. The prevailing view is that Brexit must be seen as an opportunity to start and also to master the overdue work on reshaping European Union arrangements to make them more efficient, more transparent, and more accountable. While neither the mandate nor the competences of these preliminary activities are clearly regulated, they do join in an already evolving reform process. At least since President Donald Tusk and then British PM David Cameron agreed in February 2016 on dropping the objective of an "ever closer Union" and allowing the UK - and others - to monitor migration and especially labour movements as well as further derogations from the acquis, including the right to severe social benefits for 13 years, ${ }^{7}$ the fundamentals of the EU have started to change. The Five Presidents' Report of June 2015 (Juncker et al. 2015), designed to provide a roadmap for the future, has since been relegated to the many respectable relics of history rather than to an operational policy guideline, even though it has never been formally revoked.

In short, the Five Presidents' Report is an attempt to provide answer to all questions invoking "more Europe", as already suggested by the title. In other words, more Community method, more centralisation, more qualified majority voting, and more obligatory tasks for member-states are the solution. While this is not quite in line with the spirit and wording of the Lisbon Treaty, but more in line with the practice as emerged during crisis-management, and certainly in line

Conseil Européen, Projet EUCO4/16, 2 février, 2016, eau/ion/heb.voj/GK/af/F, available via the link provided by Robert (2016). 
with the ambitions of President Juncker, seeing himself as the Premier of Europe, rather than a chief executive officer, who is accountable to the board of trustees (Henkel - Starbatty 2016).

This tendency runs counter to resistance from the member-states and the Parliament alike. The fact that the compulsory relocation agreement of 2015, earmarking a re-settlement of 160 thousand people, has actually led to the relocation of about 4.5 thousand, or a mere three per cent, shows the blatant inefficiency on the ground. ${ }^{8}$

There is no easy solution if two worldviews clash on real world issues. First, it is correct to point out that the series of concessions granted to the UK, their nature and cumulation may easily translate into an ever looser Union (Fahrmeir 2016: 172). This is rather problematic, both from theoretical and policy perspectives. From the theoretical point of view, the fundamental feature of the entire history of the EU has been a series of incremental, but irreversible moves, a step-by-step march towards finalité politique, be that sectoral policies, EMU, banking union, or social rights. Once the objective is given up, the political mechanism and the institutional dynamics of further integration is crippled - much more than by the usually invoked increased diversity owing to enlargements.

From the practical perspective, diversification has already created a major challenge to an organisation built on the Franco-German administrative tradition of detailed regulations and centralisation of decisions. To date, the policy answer to this growing diversity has been differentiation, or variable geometry around the Franco-German core Europe. However, pragmatism, much praised by those avoiding broader coherent thinking as a base for corporate or governmental strategy has reached its limits. As Chopin - Lequesne (2016) expand on the bits and pieces, this road is burdened with the very real risk of lasting fragmentation and eventual disintegration. Less national governments are attached to the European project, and the more they follow the immediate material gain-maximising behaviour conceptualised on micro-economically informed models of decisionmaking, the higher the danger of self-propelling dynamics towards disintegration. Thus, although the call to use Brexit as an opportunity is well grounded, it is easier said than done.

The EU has already entered a phase of multiple crises basically across all fields of its activity, where lack of functionality, citizen apathy, and bureaucratic over-reach mutually reinforce one another, creating vicious circles of various sorts (Gretschmann 2016: 42-44). Therefore, Brexit is more a sign than a trigger of the multi-layer crisis in integration. Still, it is legitimate to warn - as literally

The Brief from Brussels: Europe's Migration Crisis Rages on. Euronews.com, August 31, 2016. 
all of the sources cited above do - of the dangers of a self-propelling process of erosion, which may translate into a sort of spontaneous disintegration. What is happening with joint European border controls plus Schengen is perhaps a prelude, and so is the growing drift between euro zone ins and outs. This is further exacerbated by the conflict between net recipients of transfers - "Friends of Cohesion" - and the rest, the net contributor countries. The latter have been increasingly worried about the questionable efficacy of the use of funds for real convergence, rather than as simple and straightforward side payments to government loyalists (Crisp 2015). It is thus unsurprising to see controversies between the Commission and national agencies to intensify, leading to a considerable slowdown of payments in the subsequent, 2014-2020 period of funding. Let us add: the Court of Auditors received no mandate to check the economic rationale behind the projects, including their recoupment. The startling finding, that about every second euro is used in an improper manner, relates to procedural rationality only.

We tend to be more upbeat about the future of the European Union than the pessimistic accounts cited above. First and foremost: the Community has always been in a "crisis". This holds true in the sense of not attaining its broader objectives in quantitative terms and especially in due time, ever since the European Defense Community was voted down in the Assemblée Nationale in 1951. Meanwhile, a thick web of - largely compulsory - regulations and rules, extensive institutions, and - since 1999 - even a military leg have come into being. Thus, the process of deepening and widening could go hand in hand, despite twists and turns and occasional foot-dragging by some member states.

Second, the single market and the single currency have brought about palpable welfare improvements, over and above the additional growth rates calculated in econometric models. The advantages of the former are so obvious that even Brexiters want to retain access to it. Likewise, entering a currency zone counts among the commonsensical propositions of international finance literature for small open economies. The arguments we marshalled to explain why Grexit never materialised can indeed be generalised to any of the countries currently using the euro.

Third, as we have argued, Brexit constitutes a special case for European integration. True, one of the important innovations of the Reform Treaty of 2009 was precisely the opening up the possibility of exit from the Union. However, this stipulation seems to have worked only under exceptional circumstances. These included the rule of perceptions over realities, a public discourse dominated increasingly by the UKIP agenda, a historically rooted deep split in the ruling Conservative Party, and, not least, a miscalculation by David Cameron about the real political strength of the Remain camp, in intellectual and mobilisation 
terms alike. The role of unchecked information and straightforward manipulation by those who have yet to formulate their agenda months after the decision they insisted upon, speaks for itself in terms of analytical substance.

Fourth, if our description of events holds, it is highly unlikely that any current EU member would replicate the UK experience any time soon. Lacking the special circumstances - of being an island, being a former empire, being the financial centre of the globe, while not being integrated with the rest of continental Europe, either culturally or institutionally - may deter any other potential leaver. It is unsurprising that in France, for example, we do not find supporters of a "Frexit" except for the extreme right, even though the country tended to conduct self-centred policies on a number of issues, from the Middle East to the lasting economic use of nuclear power. New members count among the largest beneficiaries in economic and political terms alike. Italy is unlikely to sink its own ship, its fragile economy and restive political class, on a risky leave. And the list can be continued.

Excluding one of the polar scenarios, however, does not translate immediately into subscribing to the other one. As we discussed above, and documented also through the literature review, the current state of affairs in the EU is anything but ideal: all member states and organisations, all lines of analyses tend to be dissatisfied. The launching of major re-thinking in semi-official and official think tanks is a sign of this. Over and above the usual professional controversies that surround migration, sectoral policies, external affairs, or environmental issues, there seems to be a consent over the need to allow "managed diversity" as opposed to the drifting we deplored above. To quote Simms (2006b: 318-320), the solution is not to push the UK to become more EU-compatible, as the Commission still seems to do, but to make Europe more "British" in the sense of not requiring identical positions and allowing for more diversity in unity. This is certainly equal to the "variable geometry"' option, long feared by the smaller and less influential states of the EU. However, given the manifold and diverse splits in the Union, pushing for the Community method, as reflected in the Five Presidents' Report cited above, is likely to exacerbate rather than mitigate the problem. If Brexit illustrates anything more general, this is a case in point. As we discussed above, making concessions, even on fundamentals, without truly appreciating diverse endowments - in this case, the British imperial tradition and the focal political and economic role of the City - could only aggravate the situation.

The EU is thus in flux, with its credibility shaken and its fundamental legal arrangements questioned in behind closed doors deals. How to proceed? There are usually two basic approaches to overcoming a crisis scenario. In one approach, calling the crisis a window of opportunity, a fundamentally new arrangement is elaborated and also implemented. This happened in the post-communist transfor- 
mations in Central and Eastern Europe, and this was the case with the Thatcher reforms of the 1980s or the Swedish reforms of the 1990s. The alternative approach is that of incrementalism. In the latter view, if major disagreements prevail among the partners, only a "first things first" approach might be of avail. In the latter view, easier steps must be front-loaded, and only if a real impetus for change emerges - not least based on the convincing first results of previous measures - can one orchestrate a broader pro-reform constituency, a coalition of the willing to bring about thorough changes.

The choice depends on our perspective, set of values, objectives, and overall assessment of both the situation and what is achievable in a realistic timeframe. Following the latest book of the eminent historian Iván T. Berend (2016), we may differentiate the various phases of integration. The first one, dominated by strategic concerns - made in the USA -, the second, motivated by interests of corporate Europe culminating in the EMU, and the third, driven by considerations of the political class, namely Europeanisation. As the epilogue concludes, the specificity of the current critical juncture is that no new engine is around to move the vehicle ahead. The spread of Euroscepticism, which has gained respectability in mainstream parties and movements, is not a good sign, nor is "enlargement fatigue" and "reform fatigue". The latter usually follows the shallow and instrumental game of blaming "Brussels" for anything that goes wrong, and simultaneously claiming credit for anything good. The latter is not exclusive to the new member states - rather, the latter tended to mimic the "best practices" of the incumbents, including founding members such as Italy and France, over the past quarter of a century.

\section{POLICY OPTIONS: THE CRITICAL MASS AND SNOWBALL EFFECTS}

If the above assessment holds, the diagnosis points towards homeopathic rather than surgical options. Major disagreements among various country groups have not been triggered, but merely brought out in the open both by the threat of Grexit and the eventual Brexit. Therefore, the common platform can and should be on what agreement can be engineered via a meticulously elaborated compromise.

The silver lining is that in a crisis situation, the usual baseline scenario of "more of the same" no longer remains an option. The size of the ongoing uncontrolled mass migration has already triggered a change in the financial guidelines of the European Union as well as in the fiscal expenditure structure of many member states. The foot-dragging and no reform solutions in the Common Agricultural Policy, ironically called the Ciolos reforms for 2014-2020 (Swinnen 2015), have simply become unsustainable by now. 
Let us recall the major finding of the extensive collection of papers cited above: it has been the predominance of short-term vested interest over any broader consideration, be that greening or efficiency, targeted use of public expenditure or externalities, which has yielded this questionable result. Thus, perhaps a firstorder task would be to get negotiators away from the usual horse-trading and entrust a relatively narrow circle of highly credible experts, not bound by national bargaining positions, to elaborate something with vision, perspective and obvious value added.

In short, we should restrict ourselves to making some of the initial suggestions that we hope will be conducive to improved outcomes. The most urgent step would be to move towards consolidating the legal and institutional base of the Union. This implies the laborious work of integrating received arrangements, especially the European Stability Mechanism, the Fiscal and Banking Union, and the Single Resolution Mechanism, into the Treaty on the European Union.

Second, the thorough review of common expenditure priorities, in line with the usual half-time health check on the state of the Union, should be started, following the basics outlined above. This is not identical with the proposition of the Five Presidents' Report on enhancing supra-national implementation mechanisms for the EMU, which seems largely superfluous. Once a country opts to stay, it is likely to follow the rules of the game, by and large, or else incur considerable costs in terms of output, employment, and competitiveness. Judging by the experience of the Mediterranean countries, these are far from negligible on the macroeconomic level and especially for the longer run, meaning a five to seven years' perspective. Enforcement should be left to the combination of market processes cum domestic political action, including structural reforms that are overdue in a number of economies.

Third, ECB should return to the confines of its original mandate. By now, the ECB has developed into a fully-fledged lender of last resort, without, however, possessing the mandate of a federal central state authority (Krampf 2016). Outright monetary transactions, and especially direct bond purchasing programmes, clearly contradict the fundamental principle of banning monetary financing of governmental deficits. Likewise, the self-chosen idea of the need to care about the state of employment and capital market quotations go way beyond the logic and the letter of the statutes of the ECB. The latter reflect the fact that as long as no political integration the sense of a federation is in sight, the joint monetary authority cannot take over any fiscal functions, let alone to take on debt obligations instead of the member states. This parallel was clearly made with constituent states of the USA by Thomas Sargent in his Nobel lecture in 2011 (Sargent 2012), explaining in detail why the usual excuses, invoked daily by the ECB management, simply do not hold. 
Fourth, working groups on the future of the EU in the global system could be convened. These could produce - without convening yet another, notoriously inefficient inter-governmental conference - food for thought for further and bolder reforms, on which the Council and later the Parliament could agree. But these reflections should be conducted on a clear political mandate, coming from the member states, rather than voluntary speculations that are being conducted at university departments and think tanks anyway.

\section{CONCLUSIONS}

Comparing Grexit, which never happened, to the eventual Brexit has proven productive. We hope to have presented a simple comparative model explaining the limits and possibilities of escalating disintegration in the European Union in the form we know it today. We have highlighted why the UK is a special, non-replicable case, and why Greece, to the dismay of many, has been "normalcy". Looking into the political economy of the processes, we have assessed the implications for the Community and formulated four policy suggestions on how the EU could become more efficient, more relevant to its citizens, and better able to withstand external challenges that are likely to multiply in the future. In so doing, we avoided wild speculations about creating a new Union out of scratch. Instead, we built our proposals on a broad line of literature that allows for a more optimistic expectation and forecast than the currently prevailing doomsday scenarios do. The EU, having lost one of its strongest members, has come to a critical juncture, a real watershed. But Brexit neither caused, nor solved the challenges ahead. Business as usual implies incremental and implemented reforms to the degree it is needed for muddling through, which is indeed distinct from the no-change scenario.

\section{REFERENCES}

Berend, T. I. (2016): The History of European Integration: A New Approach. London: Routledge. Bickerton, Ch. - Hodson, D. - Puetter, U. (eds) (2015): The New Intergovernmentalism: States and Supranational Actors in the Post-Maastricht Era. Oxford-New York: Oxford University Press. Bogdanor, V. (2016): Britain and Europe. Zeitschrift für Staats- und Europawissenschaften, 14(2): $157-166$.

Chopin, Th. - Lequesne, Ch. (2016): Differentiation as a Double-Edged Sword: Member-States' Practices and Brexit. International Affairs, 92(3): 531-545.

Crisp, J. (2015): Auditors Slam 'Serious' and 'Persistent' Errors in Awarding EU Cohesion Funds. Euractiv, 15 September. 
Csaba, L. (2009a): The State of the Union: Revival or All Problems Swept Under the Carpet? In: Crisis in Economics? Studies in European Political Economy. Budapest: Akadémiai Kiadó, pp. $138-156$.

Csaba, L. (2009b): Unintended Consequences of Crisis-Management. Zeitschrift für Staats- und Europawissenschaften, 7(3-4): 450-470.

Fahrmeir, A. (2016): Allmaechlicher Abschied von der europaeischen Integration? Britische imperiale Erfahrungen, das Brexit Votum und die Europaeische Union. Zeitschrift für Staats- und Europawissenschaften, 14(2): 166-173.

Gretschmann, K. (2016): The EU in Stormy Seas. In: Dallago, B. - Guri, G. - Mcgowan, J. (eds): A Global Perspective on the European Crisis. London: Routledge, pp. 33-47.

Györffy, D. (2016): Soft Budget Constraint and the Greek Tragedy. In: Hámori, B. - Rosta, M. (eds): Constraints and Driving Forces in Economic Systems. Newcastle-upon-Tyne (UK): Cambridge Scholars Publishers, pp. 109-136.

Henkel, O. - Starbatty, J. (2016): Jean-Claude Juncker - das Schlitzohr. Frankfurter Allgemeine Zeitung, August 27.

Juncker, J. C. in close cooperation with Tusk, D. - Dijsselbloem, J. - Draghi, M. - Schulz, M. (2015): Completing Europe's Economic and Monetary Union. Available at: www.europa.eu/priorities/sites/beta-political/files/5-presidents-report_en.pdf (last accessed September 15, 2016).

Kolodko, G. (2014): The New Pragmatism, or Economics and Policy for the Future (An Essay). Acta Oeconomica, 64(2): 139-160.

Krampf, A. (2016): From Transparency to Ambiguity: The Impact of ECB's Unconventional Policies on the EMU. Journal of European Integration, 38(4): 455-471.

Krugman, P. (2015): Ending Greece's Endless Bleeding. The New York Times, July 5.

Kudrna, Z. (2016): Financial Market Regulation: Crisis-Induced Supranationalization. Journal of European Integration, 38(4): 251-264.

Lannoo, K. (2015): The Great Financial Plumbing. London - Lanham (Md/USA): Rowman and Littlefield International for CEPS.

Majone, M. - Laffan, B. - Schweiger, Ch. (eds) (2016): Core-Periphery Relations in the European Union: Power and Conflict in a Dualist Political Economy. London: Routledge.

Mac Shane, D. (2016): Brexit: How Britain will Leave Europe. 2nd, revised edition. London: I. B. Tauris Publishers.

Mosbacher, M. - Wieseman, O. (2016): Brexit Revolt: How the UK Voted to Leave the EU. London: Social Affairs Unit.

Olivier, T. - Williams, M. J. (2016): Special Relationships in Flux: Brexit and the Future of US-EU and US-UK Relationships. International Affairs, 92(3): 547-567.

Robert, A. (2016): EU Hopes Legal Gymnastics Will Avoid Brexit. Euractiv, February 18.

Sargent, Th. (2012): United States Then, Europe Now. Journal of Political Economy, 120(1): $1-40$.

Simms, B. (2016a): Britain's Europe: A Thousand Years of Conflict and Cooperation. London: Allen Lane.

Simms, B. (2016b): Scotland, the British Question and the European Problem: A Churchillian Solution. In: Atkinson, A. - Huber, P. A. - James, H. - Scharpf, F. (eds): Nationalstaat und Europaeische Union: eine Bestandaufnahme. Baden-Baden: Nomos Verlag, pp. 295-320.

Swinnen, J. (ed.) (2015): The Political Economy of the Common Agricultural Policy. Lanham (Md/ USA) - London: Rowman and Littlefield International for CEPS.

Visvizi, A. (2014): From Grexit to Grecovery: The Paradox of the Troika's Engagement with Greece. Perspectives on European Politics and Society, 15(3): 335-345. 